\title{
Technical advantages of alternative process flowsheets for Itakpe iron ore
}

\author{
AJAKA Ebenezer Oyedele*, AKANDE Jide Muili, Adesina A. \\ Department of Mining Engineering, School of Engineering and Engineering Technology, The Federal University of Technology, Akure, \\ Ondo State, Nigeria
}

\section{Email address:}

akdenezer@gmail.com (Ajaka E.O.), akandejn@yahoo.com (Akande J. M.)

\section{To cite this article:}

AJAKA Ebenezer Oyedele, AKANDE Jide Muili, Adesina A.. Technical Advantages of Alternative Process Flowsheets for Itakpe Iron Ore. International Journal of Science, Technology and Society. Vol. 2, No. 3, 2014, pp. 46-52. doi: 10.11648/j.ijsts.20140203.13

\begin{abstract}
Every mineral processing plant flowsheet is selected from several possible alternatives because an ore may be processed using a number of recovery techniques. The flowsheet that is finally selected must have certain technical or economic advantages over the others. In a redesign process of the Nigerian Iron Ore mining Company (NIOMCO) processing plant, Itakpe, five design options (described here as New Design Options A, B and C and Improved Existing Plant Options A and B) were developed as alternatives to the existing plant. Concentrates' properties, recovery ratio or efficiency and efficiency ratio are the technical parameters used as measure of plant performance. The properties analyzed for comparism include iron mineral content of the concentrate, total concentrate weight, concentrate grade, percent recovery and loss. The analyses were done by stepwise iteration of all streams in the flowsheet from comminution to the final concentrate. The results of the analyses show that the concentrate that has the best value for the new iron ore plant options is that produced by the new plant design option $\mathrm{C}$ (which employs floatation as the only recovery process) which has a concentrate grade of $70 \%$ iron mineral content representing a recovery of $95 \%$ and a loss of $5 \%$ respectively. This gives the best overall performance.
\end{abstract}

Keywords: Technical Advantages, Plant Performance, Recovery Ratio, Efficiency Ratio, Concentrate Properties, Enhanced Processes

\section{Introduction}

Recovery and production cost are fundamental factors in any mineral processing plant that must be balanced. In fact, the principal target in plant design is the achievement of maximum recovery at the least possible cost [1 and 2].

Maximum recovery implies that a very high percentage or amount of the valuable mineral is won from the ore by whatever applicable processes employed at a cost that leaves a reasonable margin for profit. The prevailing market price of the mineral concentrate is also seriously affected by the grade of the concentrate. Although endusers may specify varying grade requirements for their refining or production plants, the truth is that the higher the grade (i.e. the purer the concentrate), the higher the price, up to a limit [3, 1 and 4].

However, because of the difficulty in balancing these important factors the recovery in some processing plants is low. A good example is the Nigerian iron ore mining company (NIOMCO) processing plant at Itakpe, Nigeria which is presently losing a significant volume of its iron minerals to the waste stream as a result of the cost implications of processing the ore beyond the present number of stages. For instance Table1 shows the grades of tailing materials (iron mineral composition) of the NIOMCO processing plant compared with some from other processing plants around the globe [5]. A critical comparison of the content of the table shows that the number of process stages in the Nigerian plant may have been limited to the existing stages in order to limit process cost. Thus, the plant's tailing contains a high percentage of the valuable iron minerals. But with proper design, effective materials and process selection, systematic process integration, control and regulation of plant variables, an optimum recovery and grade can be achieved at the least possible cost [5, 2, 3 and 6]. This article is part 
of a study of the NIOMCO processing plant with the objective of improving or optimizing recovery of the valuables in the ore.

Processing minerals before export or local sale adds value to them. In cases where minerals are mined primarily for export, processing will ensure that the tailings which may contain some yet unidentified minerals and known valuables that cannot be concentrated by the present known methods are left in place until an improved technology for their efficient recovery and identification of all components is developed. This project is undertaken to improve or maximize recovery of the iron mineral from Itakpe iron ore deposit so that the $24 \%$ iron mineral content of the plant tailings is reduced to less than $10 \%$ as obtained in most plants around the world. The design will also ensure that a super concentrate is produced at minimum cost.

Table 1. Iron Tailings Composition from Itakpe and Some Foreign Plants

\begin{tabular}{|c|c|c|}
\hline Plant Location & Plant Operator (Company) & $\begin{array}{l}\text { Average \% Iron } \\
\text { Mineral in Tails } \\
\end{array}$ \\
\hline USA & Mount Wright Mine, & 9 \\
\hline \multirow{2}{*}{ Canada } & Iron Ore Company, Labrador & 11 \\
\hline & Quebec Cartier Mine & 9 \\
\hline \multirow{3}{*}{ Australia } & Olympic Dam & 7 \\
\hline & North Mining Company & 11 \\
\hline & Ernest Henry Mine & 8 \\
\hline Chile & Candelaria Mine & 9 \\
\hline Mauritania & Iron Ore Mine & 10 \\
\hline $\begin{array}{l}\text { United } \\
\text { Kingdom }\end{array}$ & $\begin{array}{l}\text { Koivusaarenneva Iron Ore, } \\
\text { Kälviä, Finland }\end{array}$ & 8 \\
\hline Nigeria & $\begin{array}{l}\text { NIOMCO Plant, Itakpe, Kogi } \\
\text { State }\end{array}$ & $>20$ \\
\hline \multirow[t]{2}{*}{ India } & $\begin{array}{l}\text { Kudremulah Iron Ore } \\
\text { Company Ltd, India }\end{array}$ & 11 \\
\hline & Kiriburu Iron Ore Mine & $60^{*}$ \\
\hline Swedeen & LKAB Iron Ore Mine & 8 \\
\hline
\end{tabular}

\section{Methodlogy}

The research work from which this article is derived undertook a redesign of the NIOMCO processing plant with a view to improving recovery and its report presented in many parts. This report deals only with the analysis of technical advantages of the different process options employed. A thorough search for available information on the latest improvements in plant design, process performance, plant control and application of artificial intelligence in mineral processing plant, equipment types and their selection criteria, mass balance, recovery and cost

\footnotetext{
* This Iron ore contains large amount of fine grained iron minerals which are not suitable as feed for the blast furnace.
}

estimation techniques was undertaken. Following comminution tests and analysis of results of series of bench scale recovery tests and determination of grades, composition and loss using appropriate techniques, the existing plant was critically analyzed and a number of alternative design options that would improve recovery were considered [7]. The flowsheets for these alternative options were developed and recovery and concentrate grades calculated. The technical details of each option were enumerated and the options and the existing plant compared on equal platform to determine their advantages.

\section{Analysis of Existing Plant}

Figure 1 shows a schematic diagram of the existing plant which is also represented by the flowsheet in Figure 2. As shown in the flowsheet, the plant consists of the comminution unit, banks of hydrocyclone used to split the primary feed into two fractions of fine overflow and coarser underflow. The two fractions are processed through several stages of gravity separation by spiral and low and high intensity magnetic separators (LIMS and HIMS). A critical analysis of the comminution and blending units shows that these are appropriate for the plant based on ore characteristics. Ajaka and Onyemaobi [7] and Soframine [8] are of the opinion that on the basis of ore properties and certain production requirements, the equipment selected for the comminution unit are appropriate both in size and proportion. Cost and revenue were calculated on the basis of this layout and compared with other design options.

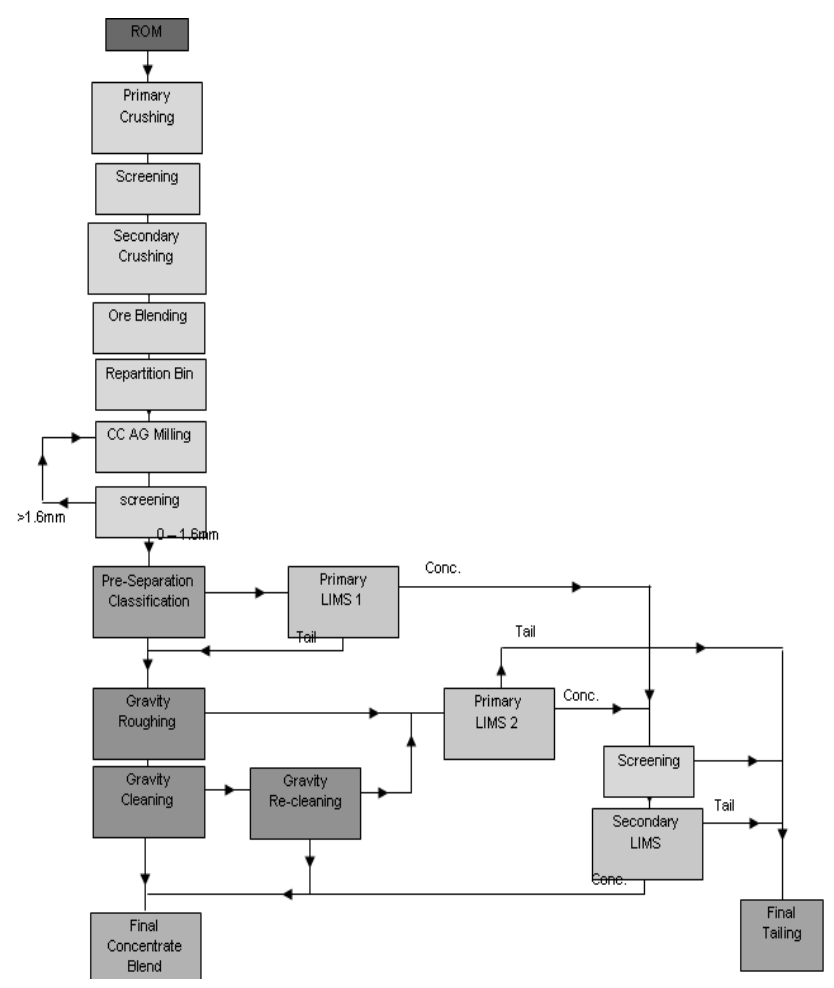

Figure 1. Schematic Flowsheet of Itakpe Iron Ore Processing Plant 


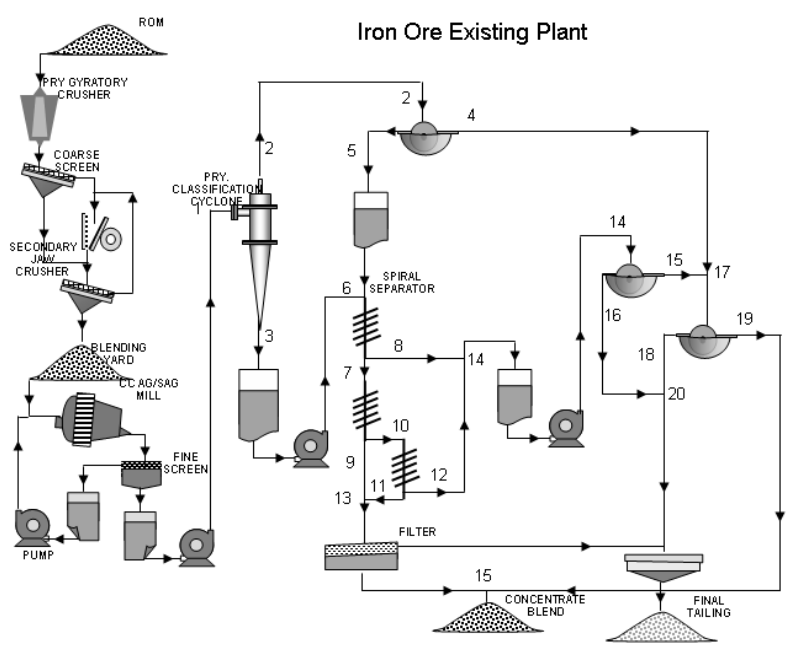

Figure 2. Process Flowsheet of Itakpe Iron Ore Processing Plant

\section{Summary of Redesign Options}

Based on the properties of the iron ore, analyses of test results and known standards in plant practice, a number of design options were considered as alternative for optimum recovery of the valuable minerals. This involved selection of the most applicable concentration processes and equipment for each design options, design and integration of the circuits, calculation of recoveries, losses and concentrate grades.

The design options according to Ajaka and Onyemaobi [7] present two possibilities. The first is to design a completely new processing plant that will give optimum recovery and thus reduce the losses in the existing plant while a second option is to introduce optimization process in the sections of the existing plant where the loses are incurred and thus improve recovery. Then the cost benefits and technical advantages of the design options are compared to make a final selection. In all, five alternative design options were considered. Three of these options are entirely new and two are improvements on the existing plant. The design options employed combinations of processes and are presented here as new plant options A, B, and $\mathrm{C}$ and improved existing plants options $\mathrm{A}$ and $\mathrm{B}$.

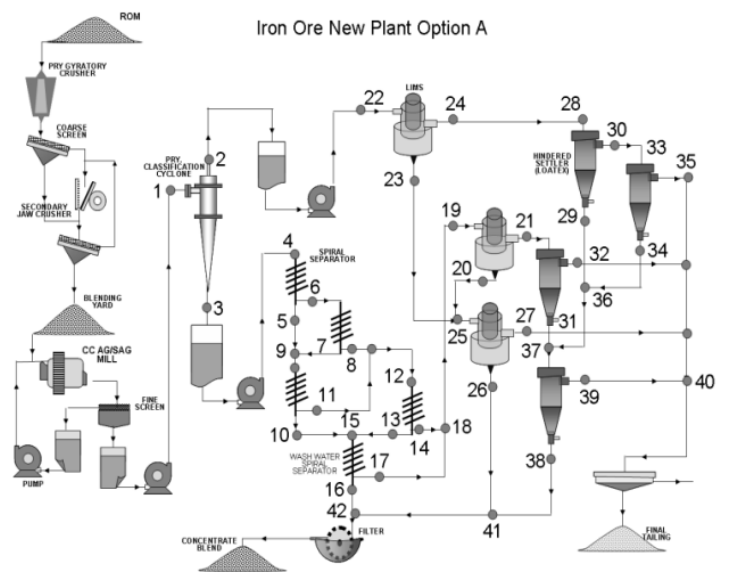

Figure 3. Recovery Flowsheet for Iron Ore New Plant Option A

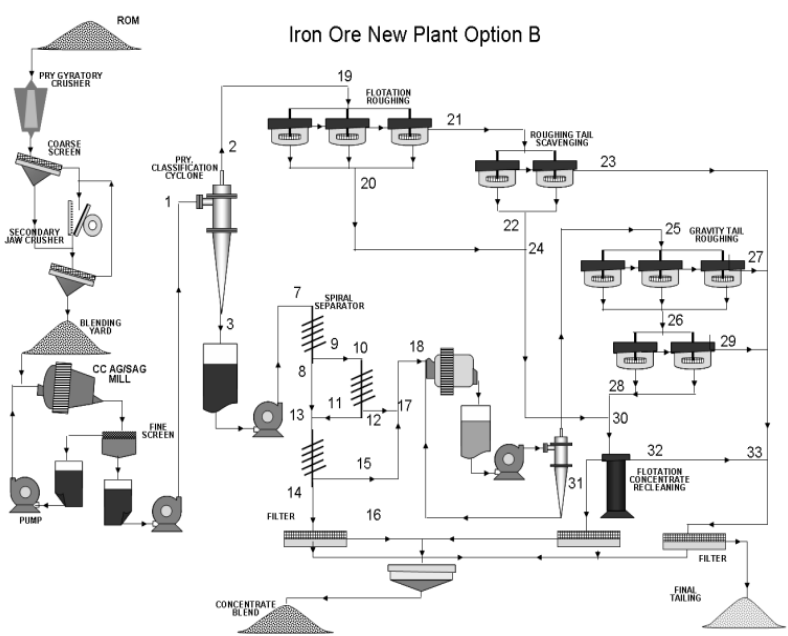

Figure 4. Recovery Flowsheet for Iron Ore New Plant Option B

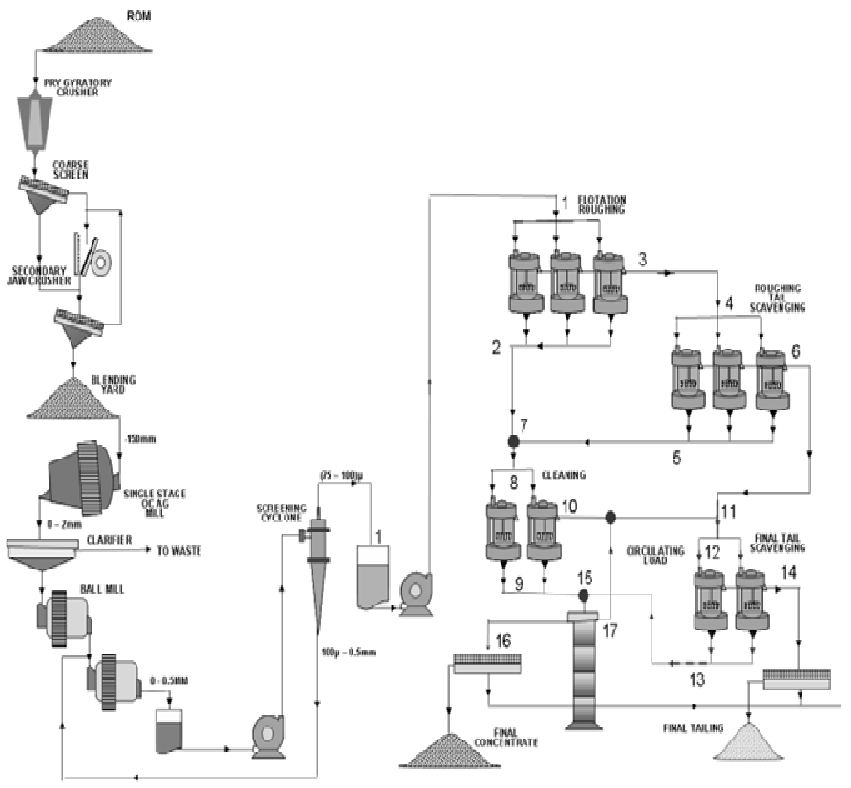

Figure 5. Recovery Flowsheet for Iron Ore New Plant Option C

New plant option A employs gravity separation and magnetic recovery process carried through several stages to ensure production of a cleaner concentrate than one obtained in the existing plant. The summary of flow process for optimum recovery of the iron minerals in this plant option are shown in Figure 3, Option B adopts some of the unit operations in Option A but employs floatation process to treat the primary cyclone overflow and for scavenging the final tail of the gravity line. The effect of this is that the plant produces a coarse concentrate and a fine concentrate which may be blended to produce a single concentrate. The flow processes are shown in Figure 4.

New plant option $\mathrm{C}$ employs floatation process to produce throughout the entire plant. The process is carried through rouging, a number of scavenging stages, cleaning and recleaning to produce a final concentrate with a circulating load to ensure optimum recovery and cleaner concentrate of higher grade. The flow process for this design option is summarized in Figure 5. 


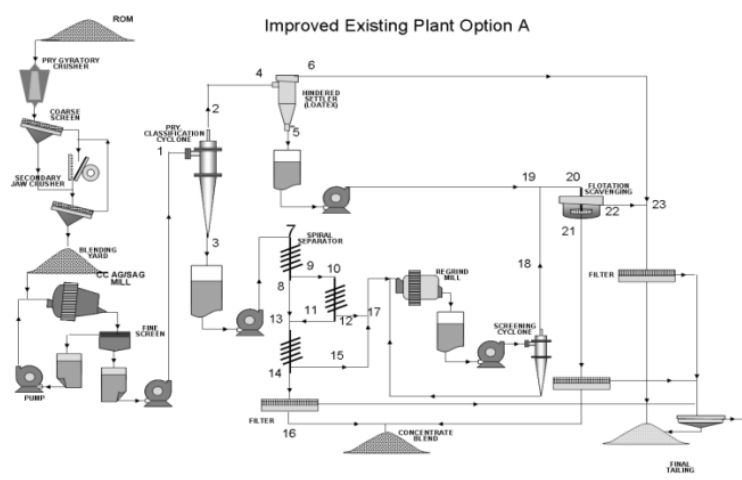

Figure 6. Recovery Process Flowsheet of the Improved Existing Plant Option A

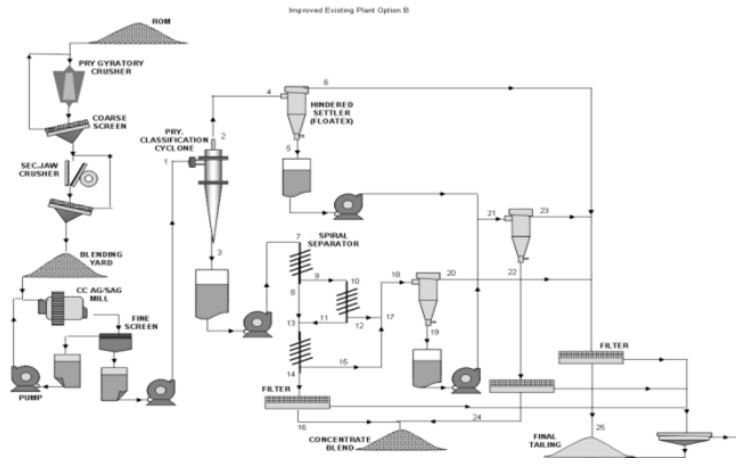

Figure 7. Flowsheet of the Improved Existing Plant Option

Option A of the improved existing plant adopts the unit operations for comminution and the gravity recovery lines of the existing plant but introduces floatation process to scavenge the final tailing stream of the gravity unit and the primary cyclone overflow fractions after roughing with an enhanced gravity process to reject some of the fine gangue minerals and other materials. The flowsheet for this option is shown in Figure 6. The improved existing plant option B also adopts the comminution process, the pre-concentration classification by hydrocyclone and the gravity concentration process of the primary cyclone underflow but employs an enhanced gravity technique to scavenge the remaining fine-grained iron minerals in the gravity tail and the primary cyclone overflow which is subsequently upgraded by cleaning in another stage using the same process. The recovery process is summarized in Figure 7.

\section{Selection of Optimum Design Options}

The various design options enumerated here were analyzed by comparing the technical advantages, recovery and loss as well as the cost effectiveness of their different flowsheets in order to select which of the options gives optimum performance. However, only the technical advantages of the various options are presented here.

\subsection{Analysis of Recovery and Loss}

Recovery and loss of iron minerals for each design option are here analyzed by comparing the properties of concentrates for each option. The properties analyzed for comparison include, iron mineral content of the concentrate, total concentrate weight, concentrate grade, percent recovery and loss. They were obtained through by stepwise iteration of all streams in the flowsheet from comminution to the final concentrate and the summary of concentrate properties (after blending and dilution where necessary) extracted as shown Table 2.

Table 2. Iron Ore Plant Variants, Parameters and their Values

\begin{tabular}{|c|c|c|c|}
\hline $\mathbf{S} / \mathbf{N}$ & $\begin{array}{l}\text { Iron Ore Plant } \\
\text { Variants }\end{array}$ & Parameters & Values \\
\hline \multirow{5}{*}{1} & \multirow{5}{*}{ Existing Plant } & Iron mineral content & $7,551.39$ tonnes \\
\hline & & $\begin{array}{l}\text { Total concentrate } \\
\text { weight }\end{array}$ & $10,787.70$ tonnes \\
\hline & & Concentrate grade & $70 \%$ \\
\hline & & Recovery & $87.4 \%$ \\
\hline & & Loss & $12.6 \%$ \\
\hline \multirow{5}{*}{2} & \multirow{5}{*}{$\begin{array}{l}\text { New Plant } \\
\text { Option A }\end{array}$} & Iron mineral content & 8026.54tonnes \\
\hline & & $\begin{array}{l}\text { Total concentrate } \\
\text { weight }\end{array}$ & $11,466.48$ tonnes \\
\hline & & Concentrate grade & $70 \%$ \\
\hline & & Recovery & $92.90 \%$ \\
\hline & & Loss & $7.1 \%$ \\
\hline \multirow{5}{*}{3} & \multirow{5}{*}{$\begin{array}{l}\text { New Plant } \\
\text { Option B }\end{array}$} & Iron mineral content & 7,987.64 tonnes \\
\hline & & $\begin{array}{l}\text { Total concentrate } \\
\text { weight }\end{array}$ & $11,358.63$ tonnes \\
\hline & & Concentrate grade & $70 \%$ \\
\hline & & Recovery & $91.87 \%$ \\
\hline & & Loss & $8.13 \%$ \\
\hline \multirow{5}{*}{4} & \multirow{5}{*}{$\begin{array}{l}\text { New Plant } \\
\text { Option C }\end{array}$} & Iron mineral content & $8,216.26$ tonnes \\
\hline & & $\begin{array}{l}\text { Total concentrate } \\
\text { weight }\end{array}$ & 12,082.73tonnes \\
\hline & & Concentrate grade & $70 \%$ \\
\hline & & Recovery & $92.90 \%$ \\
\hline & & Loss & $7.1 \%$ \\
\hline \multirow{5}{*}{5} & \multirow{5}{*}{$\begin{array}{l}\text { Improved } \\
\text { Existing Plant } \\
\text { Option A }\end{array}$} & Iron mineral content & 7,450tonnes \\
\hline & & $\begin{array}{l}\text { Total concentrate } \\
\text { weight }\end{array}$ & 10,765.6tonnes \\
\hline & & Concentrate grade & $69.2 \%$ \\
\hline & & Recovery & $86.22 \%$ \\
\hline & & Loss & $13.78 \%$ \\
\hline \multirow{5}{*}{6} & \multirow{5}{*}{$\begin{array}{l}\text { Improved } \\
\text { Existing Plant } \\
\text { Option B }\end{array}$} & Iron mineral content & 7550.2tonnes \\
\hline & & $\begin{array}{l}\text { Total concentrate } \\
\text { weight }\end{array}$ & 10,786tonnes \\
\hline & & Concentrate grade & $70 \%$ \\
\hline & & Recovery & $87.39 \%$ \\
\hline & & Loss & $12.61 \%$ \\
\hline
\end{tabular}

From the properties of concentrates of each design option enumerated above, the concentrate that has the best value for the new iron ore plant options is that produced by design option $\mathrm{C}$ which has a concentrate grade of $70 \%$ iron mineral content representing a recovery of $95 \%$ and a loss of $5 \%$ respectively. The total concentrate weight is 12 , 087.73 tonnes after adequate dilution.

One other advantage of this design option is that the flowsheet is very simple. It employs Floatation technique throughout the entire recovery circuit. Although the plant is 
designed in such a manner that the feed undergoes all stages of floatation process (i.e. roughing, scavenging, cleaning, recleaning and a circulating load to ensure production of concentrate with high and uniform grade), in actual practice, the number of process stages required to achieved the optimum concentrate grade and recovery may reduced.

When compared with options A and B, the difference in concentrate weights (which translates to addition revenue) are 189.72 tonnes per day and 278.62 tonnes per day respectively and while option $\mathrm{A}$ and $\mathrm{B}$ allows a loss of $7.1 \%$ and $8.13 \%$ iron minerals, option $\mathrm{C}$ gives only $5 \%$ loss. Although all the options have been carefully chosen and designed through those stages in order to ensure that each produces to the optimum level possible, one particular option still gives the best overall performance than the others. Before any, option is chosen as the best for the new iron ore design however, the technical must be compared with those of the other options

Comparing recovery and loss from the improved existing plant still puts new plant option $\mathrm{C}$ as the best because improve existing plant options $\mathrm{A}$ and $\mathrm{B}$ have total concentrate weights of 10,765.6tonnes and 10,786tonnes at diluted grade of $70 \%$ each against the 12,087.73tonnes at the same grade for the new plant option $\mathrm{C}$. The recoveries of $82.22 \%$ and $87.39 \%$ achieved in improved existing plant options A and B are also less than the $95 \%$ achieved in the new plant option C. However, comparing recoveries from the two improved processing plant options, puts option B in the best place.

Comparing recoveries, losses and grades in the new and improved plant options with those obtained using the same standard criteria for the existing plant shows that the existing plant is also well designed and effective. Although in reality the plant produces less than the values obtained in this evaluation, the deficiency is either due to operational problems or some inherent problems in the flow system.
The recovery ratios or losses of the various design options are determined in relation to the performance of the existing plant. The various concentrate weights may also be used to determine the relative performance of the design options in relation to one another and to the existing plant.

Table 3 and Figure 10 show the recovery ratios of the various plant options in relation to the actual production and expected production of the existing plant. On the basis of this analysis (i.e. recovery ratio), the efficiencies of the various design options were determines in relation to the expected recovery and the actual production of the existing plant.

Data obtained from the National Iron Ore Mining Company processing plant showed that the actual average concentrate weight of the existing plant is 8,680 tonnes per day if the plant ever treats up to the designed capacity of 24,000 tonnes per day (though the plant usually treats less). But the expected average recovery is $10,787.70$ tonnes per day as shown by the final concentrate of the plant. So the recovery or production ratio $(\mathrm{X})$ is here defined as the ratio of actual recovery to expected recovery. This is a measure of the efficiency of the plant.

$$
\begin{aligned}
& \text { i.e } X=\frac{\text { Actual Recovery }(\mathrm{N})}{\text { Expected Recovery }(\mathrm{M})} \ldots \begin{aligned}
& \mathrm{X} \\
& \mathrm{X}=\frac{8680}{10,787.7} \\
&=0.8046
\end{aligned}
\end{aligned}
$$

Thus, the recovery efficiency of the existing plant is about $80 \%$.

The recovery ratios or efficiencies of the various redesign options were similarly determined in relation to actual and expected recoveries of the existing plant in terms

\begin{tabular}{|c|c|c|c|c|c|}
\hline \multirow[b]{2}{*}{ Plant Design Option } & \multicolumn{3}{|l|}{ Recovery } & \multicolumn{2}{|c|}{ Plant Performance } \\
\hline & $\begin{array}{c}\text { Concentrate } \\
\text { Weight } \\
P\end{array}$ & $\begin{array}{c}\text { Recovery Ratio } \\
\text { (Actual) } \\
Y=\frac{P}{N}\end{array}$ & $\begin{array}{l}\text { Recovery Ratio } \\
\text { (Expected) } \\
Z=\frac{P}{M}\end{array}$ & $\begin{array}{l}\text { EfficiencyRatio } \\
\text { (Actual) } \\
\psi=\frac{Y}{X}\end{array}$ & $\begin{array}{l}\begin{array}{l}\text { Efficiency Ratio } \\
\text { (Expected) }\end{array} \\
\psi=\frac{Z}{X}\end{array}$ \\
\hline New Plant option A & 11,467 & 1.3211 & 1.0630 & 1.642 & 1.321 \\
\hline New Plant Option B & 11,359 & 1.3086 & 1.0530 & 1.626 & 1.309 \\
\hline New Plant option C & 12,083 & 1.3920 & 1.1202 & 1.730 & 1.392 \\
\hline Improved Plant Option A & 10,766 & 1.2403 & 0.9981 & 1.542 & 1.241 \\
\hline Improved Plant Option B & 10,786 & 1.2426 & 0.9999 & 1.544 & 1.243 \\
\hline
\end{tabular}
of concentrate weights as shown by the equations in Table 3.

Table 3. Comparing Recoveries, Plant Performance for the Iron Ore Redesign Options with the Existing Plant

Obliviously from Table 3 and as depicted in Figures 8 to 10, the new plant option $\mathrm{C}$ has the best overall performance in terms of recovery and concentrate weight. The concentrate weight, recovery, and performance ratio is higher than even the average value for all plants as shown in figures. But it cannot yet be recommended as the best option for the iron ore because the technical and cost advantages of the other design options must not overwhelmingly outweigh the cost and technical benefits of this option.

In terms of the number of individual equipment required, this is also fewer for new design option $\mathrm{C}$ than for other 
options. While option $\mathrm{C}$ employs only Floatation cells for concentration, the other options employ two or more individual equipment. For example option A employs spirals, magnetic separator and density separators while option B uses spirals and Floatation equipment; although option $\mathrm{C}$ employs three stages of grinding against one for option A and two for option B. Thus, in technical terms (both in recovery and simplicity of flow system) the new plant option $\mathrm{C}$ is better than options $\mathrm{A}$ and $\mathrm{B}$ for the iron ore beneficiation.

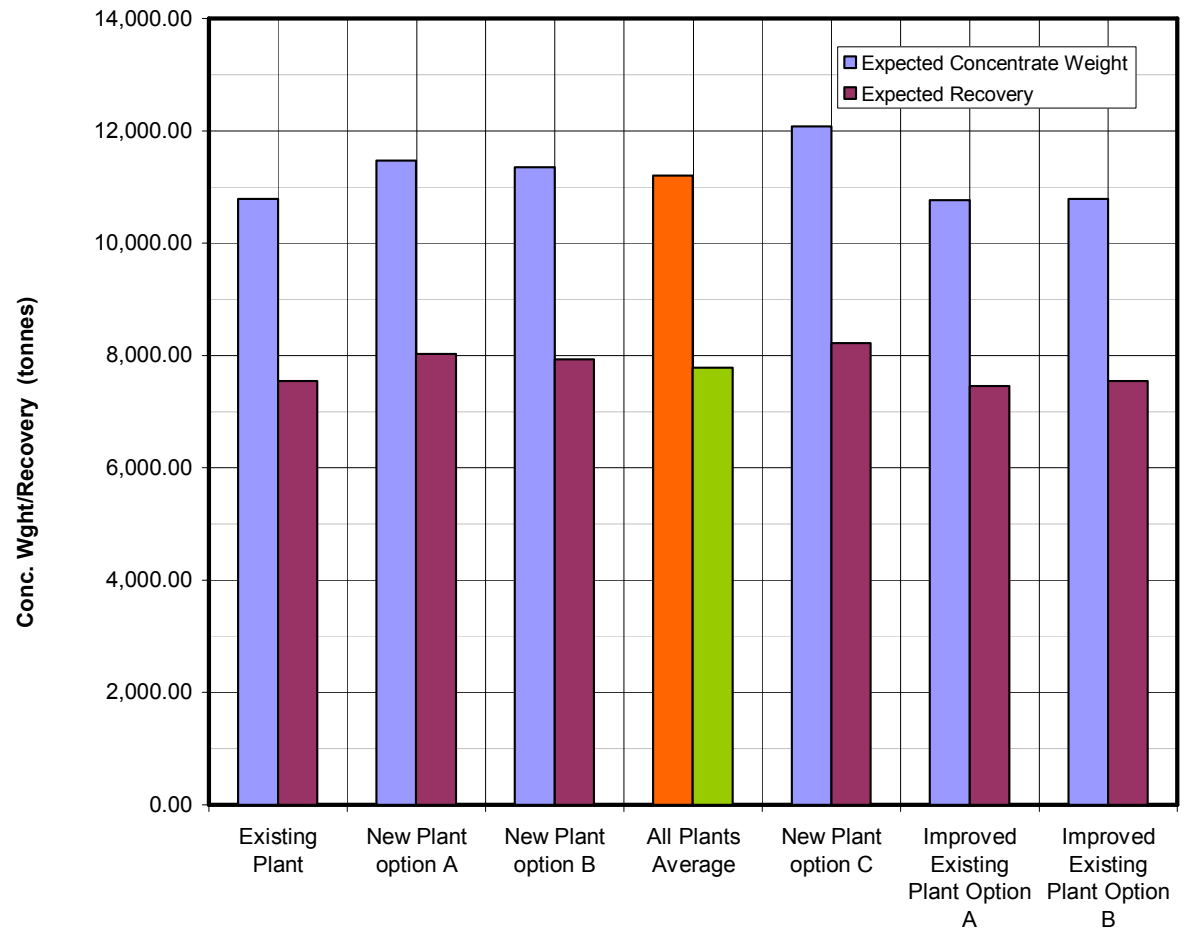

Figure 8. Iron Ore Plant Options Products' Properties Comparison

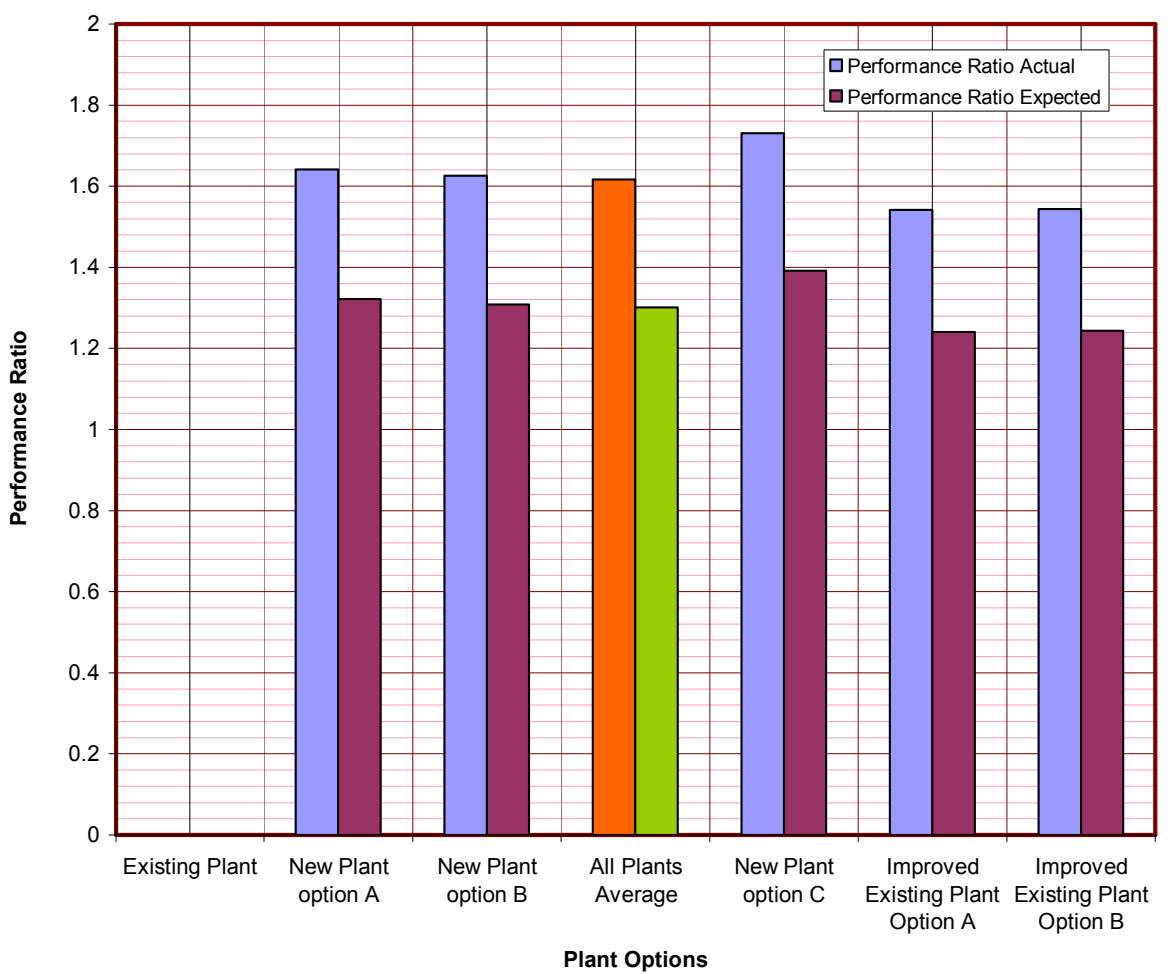

Figure 9. Iron Ore Plant Options Performance Ratio Comparison 


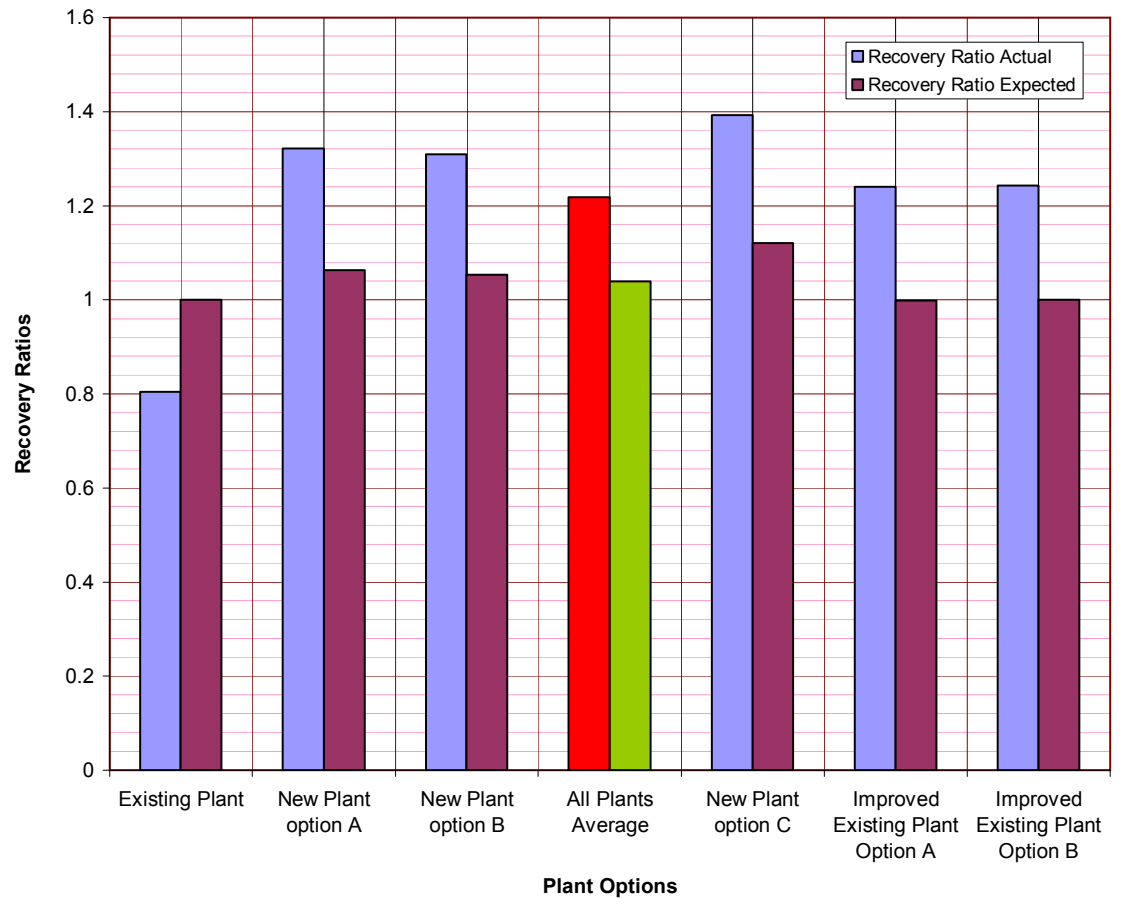

Figure 10. Iron Ore Plant Options Recovery Ratios Comparison

\section{Conclusion}

From the results of the analyses it can be concluded that the concentrate that has the best value for the new iron ore plant options is that produced by design option C. It also has a very simple flowsheet as compared to other design options.

\section{References}

[1] Scott W J., (2002): Design Criteria: The Formal Basis of Design. Mineral Processing Plant Design, Practice and Control Proceedings Vol. 1 pp 3 - 22. Edited by Andrew Mular, Doug Halbe and Derek Barratt, Society for Mining, Metallurgy and Exploration Inc. (SME), Littleton, USA

[2] Thompson, D. (2002): Bench-Scale and Pilot Plant Work for Gold - and Copper-Recovery Circuit Design. Mineral Processing Plant Design, Practice and Control Proceedings Vol.1, pp 264-269. Edited by Andrew Mular, Doug Halbe and Derek Barratt, Society for Mining, Metallurgy and Exploration Inc. (SME), Littleton, USA.

[3] Sutherland D. and Y. Gu, (2002): Guiding Process Developments by Using Automated Mineralogical Analysis. Mineral Processing Plant Design, Practice and Control
Proceedings Vol.1, pp 270-278. Edited by Andrew Mular, Doug Halbe and Derek Barratt, Society for Mining, Metallurgy and Exploration Inc. (SME), Littleton, USA.

[4] Shoemaker S. R., (2002): The Circulating Load -Practical Mineral Processing Plant Design. Edited by Andrew Mular, Doug Halbe and Derek Barratt, Society for Mining, Metallurgical and Petroleum Engineers, Inc., New York.

[5] Srivastava M.P., S.K. Pana, N. Prasada, and B.K. Mishrab, (2001): Characterization and processing of iron ore fines of Kiriburu Deposit of India. International Journal of Mineral Processing. No. 61, July 2001, pp 93-107. www.elsevier.nlrlocaterijminpro, June, 2008.

[6] American Geological Society (1997): Dictionary of Mining, Mineral, and Related Terms. 2ND Edition. Edited by Andrew Mular, Doug Halbe and Derek Barratt, Society for Mining, Metallurgy and Exploration Inc. (SME), Littleton, USA

[7] Ajaka, E. O. and Onyemaobi, O. O. (2012): Maximizing Iron mineral Recovery from Itakpe Iron Ore, Nigeria Process and Equipment Selection for Alternative Flowsheets Pan African journal of Science and Engineering, Accra, Ghana,

[8] Soframine, (1987): Evaluation of the National Iron Ore Mining Project, Itakpe. National Steel Development Agency (NSDA) - Personal communication. 